\title{
ISTINBĀT METHOD OF TABLIGHI STUDENTS IN PESANTREN TEMBORO: TEXTUAL AND CONTEXTUAL MATTER
}

\author{
Sukron Ma'mun \\ School of Social Science, Western Sydney University, Australia \\ Email: s.mamun@westernsydney.edu.au \\ Ilyya Muhsin \\ Faculty of Sharia, Institut Agama Islam Negeri Salatiga, Indonesia \\ Email: ilyya_muhsin@iainsalatiga.ac.id
}

\begin{tabular}{l|l|l}
\hline DOI: $10.21154 /$ justicia.v17i2.2003 & \\
\hline Received: 10 May 2020 & Revised: 17 July 2020 & Approved: 15 Oct 2020 \\
\hline
\end{tabular}

Abstract: This article discusses istinbāt (the way to absorb law from the main sources) of fiqh (Islamic law) by Tablighi students (santri) at Pesantren Temboro, Magetan, East Java in bahth al-masa' $\bar{a}^{\prime} i$ forum that is a forum for discussing Islamic law problems. The interesting thing of this study is Temboro Tablighi students as a traditionalist group known as the Islamic traditional community and the followers of Jamaah Tabligh. The questions are: What are the types of Islamic thought and the kinds of istinbatt used by Tablighi students? Is the istinbāt in the bahth al-masa'il forum the same as that of other students of traditional Pesantrens in Indonesia or not? This article answers those research questions not only to analyze how Tablighi students apply the istinbāt model in their forum but also to analyze the bahth al-masā'il products. This study is based on scoped library research i.e. the results of bahth al-masa' $i l$ published in Tablighi students' magazines during 2018, such as Al-Madinah, Al-Maktabah, Humairo, and Tranqil. One of the teachers involved in the forum is interviewed to clarify and get more detailed information. The results of the study show that the istinbatt method of Tablighi students, in general, is as same as other traditional students in other pesantrens which only apply qauliyyah method (using ulemas' arguments written in classical books called Kitab Kuning). This study contributes significantly on how Tablighi santri of the Pesantren Temboro remain conserving a traditional scholarship knowledge (turats) with contextualization limitedly on some cases.

Abstrak: Kajian ini mendiskusikan tentang istinbat hukum Islam atau fiqh dalam komunitas santri Tablighi di Pesantren Temboro, Magetan Jawa Timur dalam forum bahthul masail, forum yang mengkaji persoalan-persoalan hukum Islam. Hal yang menarik dari kajian ini adalah tradisionalisme santri Tablighi di Temboro yang dikenal sebagai komunitas santri salaf dan penganut Jamaah Tabligh. Pertanyaan adalah bagaimana model pemikiran hukum dan seperti apa metode istinbat yang mereka gunakan? Apakah metode istinbat hukum dalam forum bahtsul masail santri Tablighi sama dengan santri pesantren tradisional lainnya ataukah berbeda? Artikel ini menjawab pertanyaan tersebut bukan hanya untuk menganalisa bagaimana santri mengaplilasikan model istinbat hukum dalam forum bahthul masail, tetapi juga menganalisa produkproduk bahthul masail tersebut. Artikel ini didasarkan pada kajian kepustakaan terbatas, 
yakni hasil-hasil bahtsul masail yang dimuat dalam majalah santri-satri Temboro dalam kurun waktu tahun 2018, seperti Majalah Al-Madinah, Al-Maktabah, Humairo, and Tranqil. Salah satu ustadz yang terlibat dalam forum tersebut diwawancara untuk mendapatkan informasi yang lebih detail. Hasilnya, metode istinbat hukum santri Tablighi Pesantren Temboro secara umum sama dengan santri pesantren tradisional lainnya dan terbatas pada aplikasi metode qauliyyah (menggunakan pendapat para ulama yang terdapat dalam kitab klasik yang dikenal dengan kitab kuning). Kajian ini berkontribusi secara signifikan terhadap bagaimana santri Tabligh di Pesantren Temboro teguh melestarikan keilmuan tradisional (turats) dengan kontekstualisasi yang terbatas pada beberapa kasus.

Keywords: Bahth al-masā'il; Istinbāt; Islamic students of Tablighi.

\section{INTRODUCTION}

The tradition of fiqh thought at pesantren is generally dominated by Shafi'i school of thought. This domination can be seen from the efforts made to solve fiqh-related problems (masä'il fiqhiyyat) which tend to refer to the opinions of Shafi'i school. One of the Islamic law models commonly applied at pesantren is the bahth al-masá'il forum, namely a discussion forum specifically addressing Islamic law-related matters that arise amid the community. The bahth al-masa'il forum has become a tradition that is almost inseparable to the life of pesantren and traditional Islamic students in Indonesia. Broadly speaking, this forum is very effective in providing solutions to various problems to Islamic law existing in the community of pesantren and society in general ${ }^{1}$.

The problem lies in the Islamic legal istinbāt which tends to be textual, wherein it only bases the answers to problems based on the texts of fiqh books or ulemas' qaul (opinions) contained in the fiqh books. Students are confined to ulemas' opinions without doing 'ijtihad' by themselves. This case is reasonable because ijtihad, for students, is difficult to do considering the scientific capacity and complexities which must be fulfilled for conducting ijtihad. Alternatively, it is to do taqlid reasonably because the foregoing is close to the model of caution instead of carelessly doing istinbāt al-ḥukm directly from the texts, either al-Qur'an or Hadith².

Nonetheless, this assumption seems to be shifting in the tradition of bahth almasā'il. Students begin to conduct ijtihad by applying the istinbāt manhaji method,

Luthfi Hadi Aminuddin, "Istinbat Jama'i dan Penerapannya dalam Bahtsul Masail," Al-Manahij: Jurnal Kajian Hukum Islam IX, no. 2 (December 2015): 237-53; Nofialdi, "Peran Nahdatul Ulama (NU) dalam Pembangunan Hukum Islam di Indonesia," AL-QISTHU 17, no. 1 (2019): 11-18; Sukron Ma'mun, "Ilhaq dalam Bahtsul Masa' il NU; antara Ijtihad dan Ikhtiyat," Al Qalam 28, no. 1 (April 29, 2011): 63-86, https:// doi.org/10.32678/alqalam.v28i1.512.

2 Ma'mun, "Ilhaq dalam Bahtsul Masa'il NU; Antara Ijtihad dan Ikhtiyat"; Ahmad Munjin Nasih, "Bahtsul Masail dan Problematikanya di Kalangan Masyarakat Muslim Tradisional," Al-Qonun 12, no. 1 (June 2009): 106-29. 
or they even carry out legal istinbāt directly pursuant to texts, both al-Qur'an and Hadith. One example that can be presented is as conducted by students of Salafiyah Pesantren in Sukorejo, Situbondo, East Java ${ }^{3}$. The method used by such Ma'had Aly students no longer revolves around the texts of kitab kuning (Islamic fiqh books), but it is shifted to the method of manhaji. Lajnah Bahtsul Masail (LBM), The Nahdlatul Ulama Executive Board (PBNU), has also begun to move to the method of manhaji, especially in terms of thematic or contemporary issues ${ }^{4}$.

Hence, do all traditional Pesantrens also experience development like a progressive Pesantren as shown by Ma'had Aly students of Situbondo? This issue is interesting to be analyzed to see the development of Islamic legal thoughts among traditional pesantren such as Pondok Pesantren Al-Fatah of Temboro (hereafter as Pesantren Temboro), Magetan, East Java, as one of the traditional Sunni Pesantrens anchored in Shafi'i-governed school of thought.

Today, Pesantren Temboro is more popularly known as pesantren Jamaah Tabligh because this Pesantren has adopted the method of Islamic missionary and religious culture proximate to Jamaah Tabligh. This Pesantren has several students not fewer than 13,000 people coming from various regions in Indonesia, and even ones from abroad ${ }^{5}$. This pesantren also has many other pesantren affiliated with tablighi ideology in various regions in Indonesia. This shows that Pesantren Temboro and Jamaah Tabligh have a strong influence.

Historically, this Pesantren evolved within the strong tradition of nahdliyin and the fiqh of Shafi iyyah. The tradition of fiqh teaching is even strongly influenced by the tradition of Shafi'i school of thought. Kyai (Islamic grand teachers), ustad (Islamic teachers), and students still firmly hold to the Shafi iyyah fiqh tradition, but also adopt the missionary tradition of Jamaah Tabligh. Tablighi students at Pesantren Temboro also have the bahth al-masā'il tradition as found in other Pesantrens in general. Departing from this point, this article is directed to discuss two following things. How is the istinbāt method of Islamic law carried

3 See the decision results of students' bahth al-masā'il at Ma'had Aly Situbondo that have been published in the book of Editorial Team of Tanwirul Afkar, Figh Rakyat ; Pertautan Figh dengan Kekuasaan (Yogyakarta: LKiS, 2000). Other bahth al-masa'il models can also be viewed from some Pesantren traditions in Indonesia. See also M. Syarif Hidayatulloh, "Pembelajaran Kontekstual dalam Kegiatan Bahtsul Masail Santri di Pondok Pesantren Al-Muhibbin Bahrul Ulum Tambak Beras Jombang," Nazhruna: Jurnal Pendidikan Islam 1, no. 2 (August 2018): 177-200; Kudrat Abdillah, "Kontribusi Bahtsul Masail Pesantren di Madura dalam Menghadapi Perkembangan Hukum Islam Kontemporer," Perada: Jurnal Studi Islam Kawasan Melayu 2, no. 1 (2019): 67-80.

4 See the decision results of Lanjah Bahtsul Masail of NU begun in 1999, Imam Ghazali Said, Dokumentasi dan Dinamika Pemikiran Ulama Bermadzhab' dalam Solusi Problematika Aktual Hukum Islam: Keputusan Muktamar, Munas, dan Konbes Nahdlatul Ulama 1926-1999 M (Surabaya: LTNU Jawa Timur, 2004).

5 Farish A. Noor, "The Spread of the Tablighi Jama'at across Western, Central and Eastern Java and the Role of Indian Muslim Diaspora," Working Paper, 2009, https:// dr.ntu.edu.sg/handle/10220/6100; Yusuf Khummaini and Sukron Mamun, “Jodoh dan Perjodohan Santri Jamaah Tabligh di Pesantren Temboro," Ulul Albab: Jurnal Studi dan Penelitian Hukum Islam 3, no. 1 (January 12, 2020): 23-48, https:/ / doi.org/10.30659/jua.v3i1.7586. 
out by Tablighi students in Pesantren Temboro in making decisions on problems? How is the application of the istinbat method?

To elaborate on the problems, this article used a qualitative analysis using a normative approach, oriented on the study towards viewing the process of Islamic legal istinbāt undertaken by the community of the Tablighi students. In the meantime, data collection applied library research was combined with limited interviews. In such a way, the data obtained were referred to library data and those are garnered from interviews with one of the Temboro's Islamic teachers. The library data were sourced from magazines published by Temboro's students that contained the results of students' bahth al-masä'il in the 2018's edition. Those magazines comprised Tranqil, Al-Maktabah, Al-Madinah, and Al-Humairoh magazines. Besides library data, interviews were also conducted with an Islamic teacher who understood and comprehended the bahth al-masátil processed at Pesantren Temboro.

This study is also motivated by the absence of specific studies on students' tradition of Islamic legal thoughts at Temboro Pesantren. Thus far, studies concerning Pesantren Temboro have been oriented towards the issues of the pesantren education, leadership, and educational transformation from Sunni nahdilyyah to Sunni Tablighi. Several studies at the Pesantren Temboro were conducted by Arifin ${ }^{6}$ who investigated the leadership model of the Pesantren Temboro in shaping the character of society and students, Munir ${ }^{7}$ who discussed the da'wah of Jamaah Tabligh in Temboro originated from religious spirit, Al Hasyimi $^{8}$ who analyzed the impact of an ideological change from nahdliyyin to tablighi on the educational system of Pesantren Temboro, Yusuf ${ }^{9}$ who analyzed the impact of khuruj on the character building of Temboro's community, and the Romlah ${ }^{10}$ who discussed the role of Jamaah Tabligh's religious education for the community of Temboro.

See Zainal Arifin, "The Authority of Spiritual Leadership at Pesantren Temboro Based on Jamaah Tabligh Ideology," Jurnal Pendidikan Islam 6, no. 2 (December 27, 2017): 265-92, https://doi.org/10.14421/ jpi.2017.62.265-292.

7 See Ahmad Munir, “Akar Teologis Etos Kerja Jamaah Tabligh Studi Kasus Komunitas Jamaah Tabligh Desa Temboro Kecamatan Karas Magetan," Kodifikasia 11, no. 1 (August 17, 2017): 50-71-71, https:/ / doi.org/10.21154/kodifikasia.v11i1.1137.

8 See Muhammad Luthvi Al Hasyimi, “Dampak Faham Keagamaan Jama'ah Tablig Terhadap Perubahan Sistem Pendidikan Di Pondok Pesantren Al Fatah Desa Temboro Kecamatan Karas Kabupaten Magetan. Muhammad Luthvi Al Hasyimi," Jurnal Intelektual: Jurnal Pendidikan Dan Studi Keislaman 7, no. 1 (May 20, 2017): 99-108, https:/ / doi.org/10.33367/intelektual.v7i1.365.

9 Moh Yusuf, “Gerakan Khuruj Fi Sabilillah sebagai Upaya Edukasi Membentuk Karakter Masyarakat: Studi Kasus Dakwah Jama'ah Tabligh Temboro Magetan Melalui Pendekatan Framing," Kontemplasi: Jurnal Ilmu-Ilmu Ushuluddin 5, no. 1 (June 9, 2017): 165-194-194, https://doi.org/10.21274/ kontem.2017.5.1.165-194.

10 Futiati Romlah, “Peran Jama'ah Tabligh Dalam Pembinaan Pendidikan Agama Islam pada Masyarakat Desa Temboro Kecamatan Karas Kabupaten Magetan," Cendikia 9, no. 1 (2011). 
Apart from the above studies, this article provides a special focus on the tradition of students' fiqh istinbāt/thoughts in the bahth al-masā'il forum whose results were published in Temboro students' journals. The discussion of this article is compiled systematically, starting from the theoretical study of ijtihad and taqlid, a description of legal istinbāt in the bahth al-masä'il of Tablighi students, application in several issues, to the textuality of Tabligh students' Islamic legal istinbāt.

\section{IJTIHAD AND TAQLĪD}

At the end of the Abbasid Caliphate, ijtihad ${ }^{11}$ began to be rarely carried out, and taqlid gradually began to appear and infect Muslims. Taqlid era was a period of ulemas' weak enthusiasm for doing ijtihad by referring to the Qur'an and Sunnah and then doing istinbāt on a case with no legal explanation ${ }^{12}$. Muslims limited themselves in the circles of schools of thoughts, such as Abu Hanifa, Malik, Shafi'i, or Ahmad bin Hanbal. Their seriousness focused on studying and understanding the words of the Imams (great ulemas), but not understanding nas (texts) directly by doing ijtihad ${ }^{13}$. Therefore, stagnation in terms of Islamic legal guidance occurred. As a matter of fact, changes and progress in various fields always take place ${ }^{14}$.

According to Khalil, at that time, it was found that the spirit of fuqahas' independence already died and turned to taqlid, without any enthusiasm to look for breakthroughs of enthusiasm. They positioned themselves in a narrower space, namely Islamic schools of thought that might not be passed over or skipped over. Enthusiasm only arose for taqlid to follow the existing schools of thought ${ }^{15}$.

Many things cause Ijtihad to stop. In the book titled Ikhtiṣār Tārīkh al-Tashri' by Khon ${ }^{16}$, it is written that there are four factors making ijtihad stopped according to Khallaf. First, the divisions of Islamic state into several kingdoms that were against one another. Such a situation and condition gave rise to a crisis that weakened science and art enthusiasm. Second, the divisions of mujtahid imams were divided into several groups; each group had its own law. There were times

11 Ijtihad is interpreted as a serious effort to undertake legal istinbath in a direct way from nash (texts), either al-Qur'an or Hadiths, See Abdulah Safe'i, "REDEFINISI IJTIHAD DAN TAQLID: Upaya Reaktualisasi dan Revitalisasi Perspektif Sosio-Historis," ADLIYA: Jurnal Hukum dan Kemanusiaan 11, no. 1 (2017): 25-40, https:/ / doi.org/10.15575/adliya.v11i1.4850; Nur Khasanah, Achmad Irwan Hamzani, and Havis Aravik, “Taqlid dan Talfiq Dalam Konsepsi Hukum Islam,” Mizan: Journal of Islamic Law 3, no. 2 (December 13, 2019): 155-68, https:/ / doi.org/10.32507/mizan.v3i2.489.

12 Abdul Majid Khon, Ikhtișār Tārīkh al-Tashri', 2nd ed. (Jakarta: Amzah, 2015), 143.

13 Muhammad Muhdi Karimuddin, "Kedudukan Madzhab, Taklid dan Ijtihad dalam Islam," Al-Qadha 6, no. 1 (January 2019): 55-65.

14 Khon, Ikhtișār Tārikh al-Tashri', 118.

15 Rasyad Hasan Khalil, Tārìkh al-Tashri' (Jakarta: Amzah, 2009), 118; In the meantime, some ulemas suggested doing ijtihad jama'i, see Nadirsyah Hosen, "Nahdlatul Ulama and Collective Ijtihad," New Zealand Journal of Asian Studies 6, no. 1 (June 2004): 5-26.

16 Khon, Ikhtișār Tärīkh al-Tashri', 150-51. 
that for the sake of defending their schools of thought, each group argued against one another in a way that put forward other schools' mistakes. In so doing, the personality of an ulema became shattered and the enthusiasm of thinking became short. Hence, an alim could be just like a Muslim layman. Third, Muslims ignored the legal system. At the end of the fourth century of Hijri, they were also unable to formulate regulations that could guarantee that only were those skilled in the field involved in doing ijtihad. Finally, the ulemas were struck by characters such as envy, selfishness, and arrogance. Accordingly, they could not reach the level of mujtahid.

Such conditions made Muslims only doing taqlid to the results of previous ulemas' ijtihad. Khali1 ${ }^{17}$ mentioned four factors leading to the rise of taqlid. First was bookkeeping of schools of thought, wherein Islamic fiqh had been written and used as a reference to answer problems occuring in the community. Therefore, it is easy to know the solutions quickly from the books of Islamic schools of thought. Besides, almost all problems have been written in the books. Second was a fanaticism of schools of thought, wherein in that day Islamic scholars mostly devoted their propaganda to spread the teachings and opinions of the Imams' schools of thought. Recently, it even reaches the level whereby someone does not dare to have different opinions from the Imam's thought that he adheres to. Third was the position of judges, wherein in that day leaders prefered the judges who can only do taqlid on certain schools of thought. Fourth, the door to ijtihad has been closed. It relates to the case that at the end of the fourth century of Hijri, there were people who made fatwa and dug up Islamic laws, while they were far from understanding of the rules and bases of fiqh, leading them to talk about religion without knowledge. This condition raised an appeal to close the door of ijtihad so that those who claimed themselves as mujtahid did not act freely, and this way could save the public from misleading fatwas. Nevertheless, this case has a negative effect on Islamic fiqh that make it becomes old-fashioned and under-developed.

Subsequently, according to Khon ${ }^{18}$, the era of taqlid was marked by the appearance of various taqlid ulemas. There were at least five levels. The first was ahl al-ijtihäd fi al-madhhab. This group did ijtihad in dealing with new problems by holding on to the opinions set by the mujtahid imams in an absolute way. The second was ahl al-ijtihäd fi al-masä'il. This group did ijtihad in terms of matters that have not been previously studied in ijtihad ways by referring to the bases of tashri' or ijtihad bases held by the imams, and this group analogized the branches of those bases. The third was ahl al-tarjị. This group only compared different

17 Khalil, Tarih Tashri', 120-21.

18 Khon, Ihtisar Tarih Tashri'. 
narrations narrated by an imam, and then they took one of them as the strongest basis, in terms of both riwāyat and dirāyat. The fourth was ahl al-takhrīj. This group did not do istinbāt but explained the 'illat of law studied by their imam in a way of istinbat. They determined what was intended by the imam form the law which had two meanings. Then, they conducted ijtihad to explain the points taken by the imam in istinbāt. Lastly, the fifth was ahl al-taqlid. This group contained pure taqlid experts. They cannot do the previous experts' work such as takhrij, tarjih, and others. However, they still have superiority, namely the ability to distinguish between odd and clear riwāyat, and between strong and weak bases.

\section{PESANTREN TEMBORO AND THE TRADITION OF FIQH}

Pesantren Temboro is a traditional pesantren (salaf) established before the independence of Indonesia by Kyai Shidiq. This Pesantren's pioneering period has already begun since 1939, when Kyai Shidiq built a mosque later on named Al-Fatah on May 1st, $1939^{19}$. This Pesantren constantly developed although the number of students was not so large yet. However, the students' development gained an increase considerably since the leadership of Pesantren shifted to Kyai Shidiq's son, named Kyai Mahmud. He began to move the Pesantren education system by adding the learning system. Gradually, the Pesantren began to develop well. Finally, Kyai Mahmud expanded the reach of Pesantren education by establishing Islamic junior high school, Junior high school, religious teacher education, Islamic senior high school, senior high school, madrasa khufadz, and others ${ }^{20}$.

The Pesantren Temboro, like other traditional Pesantren, is Sunni-based Pesantren resting upon Shafi'i school of thought. It is just that the Pesantren has added the style of Jamaah Tablighi Da' wah system ${ }^{21}$ since the arrival of the Jamaah Tablighi group from Pakistan led by Professor Abdusobur Khan in 198422. It was from the late 1980s that Tablighi dominance began to strengthen and made the Pesantren to become the largest Tablighi education center in Indonesia. Many

19 Fadhil Bangka and Amin, "Kawah Candradimuka Itu Bernama Al-Fatah (Bagian 1 Selayang Pandang Pesantren Al-Fatah)," Majalah Tranqil, 2018, 31-35.

20 Khummaini and Mamun, "Jodoh dan Perjodohan Santri Jamaah Tabligh di Pesantren Temboro."

21 Jamaah Tabligh is a translational religious movement that has succeeded in making ideological expansion to several countries, see Sukron Ma'mun et al., "Jamaat Tablighi and Negotiation of Identity in the Global World," Opcion 36, no. 26 (2020): 821-32; Sukron Mamun, "Tablighi Jamaat, An Islamic Revivalist Movement and Radicalism Issues," Islam Realitas: Journal of Islamic E Social Studies 5, no. 2 (December 18, 2019): 145-59, https://doi.org/10.30983/islam_realitas.v5i2.1098; Jan A Ali, “Islamic Revivalism: The Case of the Tablighi Jamaat: Journal of Muslim Minority Affairs: Vol 23, No 1," Journal of Muslim Minority Affairs 23, no. 1 (2003), https:/ / doi.org/10.1080/13602000305935; Barbara D. Metcalf, "Living Hadith in the Tablighi Jama`at," The Journal of Asian Studies 52, no. 3 (1993): 584-608, https:// doi.org/10.2307/2058855.

22 Farish A. Noor, Islam on the Move: The Tablighi Jama'at in Southeast Asia (Amsterdam: Amsterdam University Press, 2012). 
students were sent to India to study religion alongside learning about religious propaganda in the style of Tablighi.

At present, Pesantren Temboro is a large Pesantren having no fewer than 13,000 students, both settlers and non-settlers. The detailed number of settler students is as many as 10,450 people, and those of non-settlers mean that they live around the Pesantren, and they are 1,935 people. The number of Islamic teachers reaches 810 people, the total number is 13,155 people. Not to mention the students scattered in the branches of the Pesantren that reach the number of 6,409 students. The Pesantren now has no fewer than 60 branches in Indonesia spread across various regions. The total number of all Temboro students both living in Temboro or in the branches of Pesantren Temboro reach the number around 19,604 people. Of that number, 646 students are from abroad ${ }^{23}$.

In the field of education, especially fiqh teaching, the majority of curriculum used is kitab kuning by Shafi'i school of thought such as al-Mabādi' al-Fiqhiyyat (Umar Abdul Jabar), Fathal-Qarīb (Shaykh Muhammad ibn Qasim Al-Ghazi), Fath al-Mu'in (Sheikh Zainudin ibn Abd al-Aziz al-Malaibary), Fath al-Wahhāb (Sheikh Zakariya al-Ansory), Al-Salām (Abd al-Hamid Hakim), Sharah al-Waraqāt fi 'Ilmi Ușūl al-Figh (Jalaludin Muhammad bin Ahmad al-Mahali al-Syafi'i), and Minhāj al-Ṭälibin (Imam Yahya bin Syarifuddin al-Nawawi) ${ }^{24}$. Looking at the fiqh curriculum, it can be understood that the Islamic legal thoughts of Tablighi students in Temboro are dominated by the Fiqh of Shafi'i school.

\section{ISLAMIC LEGAL ISTINBĀT METHOD OF TABLIGHI STUDENTS}

Istinbāt means to find or to create ${ }^{25}$. This word also has the meaning for water that comes out of the well which is excavated for the first time ${ }^{26}$. Aligned with the foregoing, Hilal states that the word means making water out of the ground ${ }^{27}$. The common ground of this word is something just obtained from the source.

In the context of Islamic legal istinbāt, the term istinbāt might be understood as an attempt to find out the law from its source, namely the Qur'an and Sunnah. This is in line with what is expressed by Sanu ${ }^{28}$ that istinbāt means the effort to get meanings from texts concerning difficult and important things by making use

\footnotetext{
23 "Santri Pondok Pesantren Al Fatah Temboro Mencapai 19.604 Santri, 646 Santri Dari Luar Negri," CAH TEMBORO (blog), accessed May 4, 2020, http:/ / cahtemboro.blogspot.com/2016/12/ santri-pesantrenal-fatah-temboro.html.

24 See the curricular book of PP Al-Fatah, "Al-Kutub al-Muqorroroh, Program Pondok Pesantren Al-Fatah Temboro Karas Magetan Jawa Timur" (PP Al-Fatah Temboro, no date).

25 A. Warson Munawwir, "Kamus Al-Munawir," in Kamus Al-Munawir (Surabaya: Pustaka Progressif, 2007), 1397.

26 Khalil bin Ahmad Farahidi, Kitāb Al-'Ain (Beirut: Dar al-Kutub al-Ilmiyah, 2003), 184.

27 Haitsam Hilal, Mu'jam Muṣțalah al-Ușūl (Beirut: Dar al-Jael, 2003), 27.

28 Qutb Musthafa Sanu, Mu'jam Mușțalahāt Ușūl al-Figh, 1st ed. (Damaskus: Dar al-Fikr, 2000), 61.
} 
of reasoning power and optimal abilities ${ }^{29}$. Such meaning still represents quite broad understanding because the meanings obtained from the texts, both the Qur' an and Hadith, are not necessarily about the law. However, the Ușūl al-Figh ulemas tended to give an understanding that istinba t inclines to be on the legal aspect. Thus, istinbāt is a serious attempt to find law extracted directly from the Qur' an and hadiths.

The term istinbāt certainly tends to be or more proximate to the meaning of ijtihad. However, looking at the requirement and mechanism of ijtihad, it is of course very difficult to be conducted by the Islamic community in general, likewise for students who are in the process of studying religious knowledge. It is because legal istinbāt is ideally conducted by people who have complete knowledge. Therefore, the term istinbāt here is more interpreted as a serious effort to find Islamic law.

Tablighi students are alike other salaf students of nahdliyyin traditional pesantren. They have a tradition of learning to explore Islamic law traditionally. They have discussion forums that are sometimes held weekly on a small scale or monthly to learn to find Islamic law on various issues that arise. Such forums are called bahth al-masä'il, which is a discussion of various problems that arise in society. The terminology of bahth al-masä'il is commonly known in various traditional pesantren of nahdliyyin.

For students of traditional pesantren, they know this forum both on small and large scales. The small scale is usually held in a class by involving all class members. Usually, students regularly hold this forum weekly according to mutual agreement. The larger forum is usually held by all students at various levels or classes. They hold such a forum once a month, per semester, or once a year.

The bahth al-masä'il implementation is coordinated by students independently, and it sometimes becomes the official agenda of learning activities. This forum is essentially an effort to learn alongside trying to solve problems they face in daily life or society. Likewise, the students of Pesantren Temboro also undertake bahth al-masa' $\bar{a}^{\prime} i l$ as students' routine agenda on both small and large scales. The results of their bahth al-masä'il are even also written and distributed through journals owned by students.

The Pesantren Temboro has a firm bahth al-masa'il forum held every Friday night. The bahth al-masa' $\bar{a}^{\prime} i$ activities of Temboro students are carried out at every madrasah. Even, according to Ustadz Imron, one of the teachers at the Pesantren Temboro, the number of bahth al-masä'il forums reaches 50 assemblies.

29 M. Alim Khoiri, “Ijtihad Kontemporer: Konsepsi, Urgensi dan Kritik terhadap Isu Tertutupmnya Pintu Ijtihad," SAMAWAT 2, no. 2 (December 1, 2018), http://jurnal.staiba.ac.id/index.php/samawat/ article/view/80. 
"Students undertake bahth al-masā'il every Friday night. They discuss problems that arise amid students and the community asking. The forums are attended by students who have already been in the takhasșșuṣ (special) class. The students are commonly those who almost graduate" ${ }^{\prime \prime 30}$.

In general, the method of Islamic legal istinbāt applied by Jamaah Tablighi students of Temboro is the same as other traditional pesantren students. They refer to the books written by the Shafi'i school of thought which are mu'tabarah, classic books that can be scientifically verified. Essentially, these mu'tabarah books are anchored in the fiqh book written by one of the four schools of thoughts.

As common to the tradition of salaf pesantren, Jamaah Tabligh students of Temboro also refer to the majority of Shafi'iyah books such as Sharah al-Nawäwi, I'ànat al-Ṭālibìn, Fath al-Bārì, Fath al-Mu'ìn, Fath al-Qarìb, al-Majmū', Bughyat alMustarshidīn, Kifāyat al-Akhyār, Minhāj al-Ṭālibīn, and others. These books are not only used as references for various religious matters but are also studied by students.

An interesting matter found in the tradition of istinbāt amid the Tablighi students are most of them only using the books grounded in Shafi'i school. If the law is not found in the Shafi'iyyah books, they will refer to the al-Maktabat al-Shàmilat, a collection of books consisting of various scientific insights from several schools of thought. Al-Maktabat al-Shamilat contains the books of Fiqh, Hadith, Tafsir, Aqidah, Adab, general knowledge of Islam, and Fihris (index). This is also applied by the traditional group of nahdliyyin. They almost refer to Shafi'i school although it does not rule out the possibility that they refer to other schools of thought as well. However, the intensity is very low. This way cannot be avoided because the Shafi'iyyah books are those widely studied. Consequently, their knowledge pertinent to the fiqh of other schools of thought is very limited.

"Book references used as the materials to search for Islamic law are the books of Shafi'i school of thought. Usually, if the students do not or have not yet found the law in the books they refer to, this case will become their homework. They will look for it in al-Maktabat al-Shàmilat. Later, when they have got it, they will discuss it in the next bahth al-masā'il meeting ${ }^{31}$.

Generally, the process of making legal decisions in the forum of students' bah th al-masä'il can be described through several processes. First, there is a problem proposed. The problem can be one directly experienced by students or people outside the Pesantren, or one asked by the community. Second, the raised problem is identified to be used as a discussion material in an agreed forum. At some point, the problem becomes a priority that needs to be answered; maybe it has

Ustadz Imron, a personal interview, Ausgust 2019.

31 Imron. 
already been discussed, or it has not been answered. Third, the bahth al-masä'il forum consists of special students who have sufficient knowledge to read books or have studied many fiqh books. Fourth, the results of the discussion are noted by writing the answers and maraji' or book references.

Although the majority of the students refer to Shafi'iyyah books, it seems that there are no official rules regarding the classification of books based on their hierarchies. The students more likely refer to books that are known as long as the validity of books is not questioned by academicians at pesantren. It is different from Lajnah Bahtsul Masail of NU (LBMNU), which suggests prioritizing certain books if there is a counterargument. In the decree of LBMNU agreed in the 1st Congress in Surabaya in 1926, it was stipulated that the opinion hierarchy was decided if counterarguments existed ${ }^{32}$.

1. Opinions in the agreement between Imam Nawawi and Imam Rafi'i.

2. Opinions chosen by Imam Nawawi only.

3. Opinions chosen by Imam Rafi'i only.

4. Opinions supported by many ulemas.

5. The smartest ulema's opinions

6. Opinions of the most careful and elaborate ulema.

This hierarchy is a guide referring to the ideal Shafi'i school of thought. However, it seems that this way is not applied by the Tablighi students. Thus far, they refer to many of the most possible books if there is a problem. Nonetheless, Shafi'i school of thought still becomes a priority for the students. It is evident that if they are unable to find opinions in Shafi'iyyah books, they will refer to Maktabah Shamilah.

If there is a legal decision-making system with four levels in LBMNU, it seems that Tablighi students tend to only take one or two levels. The four levels ${ }^{33}$ used in LBMNU are as follows: first, In a case when the answer can be sufficed by 'ibarat, and there is only one qaul or wajah, qaul or wajah are then used as explained in 'ibarat. Second, In a case when the answer can be sufficed by 'ibarat book, and there is more than one qaul or wajah, taqrír jamā $i$ is then used to have one qaul or wajah. Third, In a case that there is no qaul or wajah at all in providing a solution,

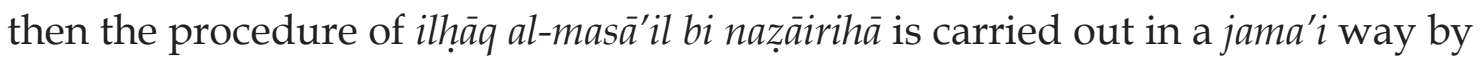

32 A Aziz Masyhuri, Masalah Keagamaan Hasil Muktamar dan Munas Ulama NU Kesatu 1926 s.d Ke-29 1994 (Surabaya: PP RMI dan Dinamika Press, 1997), 367; See also Said, Dokumentasi dan Dinamika Pemikiran Ulama Bermadzhab' dalam Solusi Problematika Aktual Hukum Islam: Keputusan Muktamar, Munas, dan Konbes Nahdlatul Ulama 1926-1999 M, xxxiv.

33 Masyhuri, Masalah Keagamaan Hasil Muktamar Dan Munas Ulama NU Kesatu 1926 s.d Ke-29 1994, 364; See also Rifyal Ka'bah, "Formulasi Hukum Di Kalangan NU," in Kritik Nalar Fiqih NU: Transformasi Paradigma Bahtsul Masa'il (Jakarta: LAKPESDAM NU, 2002), 40; compare with a paper written by Husein Muhammad, "Tradisi Istinbath Hukum NU: Sebuah Kritik," in Kritik Nalar Fiqh NU: Transformasi Paradigma Bahtsul Masa'il (Jakarta: LAKPESDAM NU, 2002), 27-35. 
the experts. Fourty, In a case that there is no qaul or wajah at all, and ilhāq is not possible to be applied, istinbāt jamā $i$ can be undertaken with the procedure of school of thought in a manhaji way by the experts.

Based on the results of several decisions made by Temboro students, there are three levels. First, one problem is sufficed by one qaul or wajah only. The answer tends to be concise and straightforward to the point of law without explanation because it is sufficed by qaul in the book, for example, may, may not, valid, invalid, obligatory, sunnah, haram, makruh, and others. Second, for one problem with many qauls or wajahs, commonly two or more qauls, the answer, however, also tends to be short and straightforward to the point of the intended law. Third, there is a problem with detailed answers and many qauls delivered. Such answers are conveyed for cases that require certain explanations, not just providing legal answers, or black-and-white answers.

\section{THE IMPLEMENTATION OF ISTINBĀTT METHOD}

The qauli method dominating legal istinbāt in Tablighi students' bahth al-masă'il can be viewed from several Islamic legal decisions that have ever been discussed. It can be said that this method is the most dominantly applied in every legal decision in bahth al-masä'il.

The following are a few examples of the application of qauli method used in students' bahth al-masa'il forum. These examples are presented according to the classification of qauli method: one qaul, a combination of qauls, and analytical qaul.

1. One qaul or one reference from ulema's opinion

The first example is taken from the 16th edition of Al-Maktabah magazine ${ }^{34}$. There is a question posed as follows 'is someone, whose job makes him always travel long distances such as an inter-city and provincial bus driver, allowed not to fast?' This question is answered using one opinion (qaul) taken directly from the book titled I'ànat al-Tâlibìn, volume II, page 632. The answer given indicates two varied opinions; 1) It is permissible if he believes that he will have an opportunity to replace his fasting in other months excluding Ramadhan. 2) it is permissible.

The second case example is taken from the results of students' bahth al-masä'il published in the 2nd edition of Humairo magazine ${ }^{35}$. There is a problem proposed in bahth al-masa'il, namely 'how is the law on female congregational prayer (salat) in the mosque where female worshipers are positioned beside male worshipers, but they are separated by fabrics?' This case is answered that female congregational prayer is 'valid'. This answer rests upon the Minhāj al-Tälibinn book, page 22.

\footnotetext{
34 Darul Ifta' Al Fatah, "Masa'il Fiqhiyyah: Keputusan Bahtsul Masa'il Spesial Romadhon," Majalah AlMaktabah, 2018, 65.

35 Darul Ifta', “Bahtsul Masail," Majalah Humairo Santri Putri Al Fatah Temboro, 2018, 57.
} 
The answer given based on the model of one qaul method tends to be brief without analysis by basing the answer directly on the book contents. Such an answer is given because the question is clear; there is a reference to the question, and it does not lead to different or conflicting opinions. Such a model is like the method of legal istinbāt in the bahtsul masail of NU at the first level, that is, if there is an adequate explanation of one qaul or opinion, the qaul is then sufficient.

2. A combination of qauls or some references from ulemas' opinions

An example of the problem discussed by students has been published in the 2 nd edition of Humairo magazine ${ }^{36}$. There is a problem concerning 'how is the low on the prayer of someone wearing a prayer hijab decorated with cartoon pictures?' The answer to this problem refers to two opinions cited from Minhäj al-Tălibìn on page 303 and Tuhfat al-Muhtāj, volume 3, page 302. The answers are very textual as provided exactly in the texts of the books, in that if the pictures are in the form of a whole living creature, the prayer is valid but haram.

This second istinbāt model, i.e. with two or more qaul, tends to see the legal problem that is quite complicated and requires a slightly complex answer. In addition, qauls or opinions that students found in kitab kuning that they have read is quite a lot. Therefore, opinions from one another from diverse sources tend to reinforce each other. It seems that the model of conflicting opinions has not yet been found, so it requires students to make a choice based on hierarchy or the level of knowledge depth and the ulemas' carefulness.

\section{Analytical Qauli}

This third model of legal istinbāt is the answer to a quite detailed problem with a specific explanation. The qaul given are not merely one or two, but many references are provided. Therefore, it can be said that this istinbāt model is part of the effort to a quite comprehensive legal answer.

The following is an example of legal istinbāt using the analytical qaul model, taken from the 13th edition of Al-Madinah magazine ${ }^{37}$ concerning the law on praise before congregational prayer begins. In dealing with such a problem, the deliberation gives a fairly detailed answer by considering some qaul. In detail, the answer is written as follows:

"The original law on praise (shalawat between adzan and iqamah) is mubah (allowed), even recommended (sunnah). However, if some people in an area feel disturbed, and some others feel that they get benefits from the practice, the legal details are as follows:

a. If maslahat is seen as more than the mafsadat (damage), for example, there is an educational content therein such as narrating nasab or the family of the Prophet

36 Ifta', 56

37 Tim Bahtsul Masail, “Masail: Kreteria Alat Musik Yang Diharamkan Dalam Shalawatan,” Majalah AlMadinah, 2018, 19. 
(PBUH), knowing the obligatory natures of Allah or things functioned as to give a sign that iqamah has not been echoed, then implementing such praise is made more necessary.

b. If the mafsadat (damage) is more than the benefit, then the law on praise in this context is makruh.

c. If it is conducted to the extent of hurting others, then the law is makruh.(See Bughyat al-Mustarshidīn on page 84, Hawāshì al-Sharwāni Juz 5 on page 107, and Sunan Nasai juz 2 on page 48).

The above example illustrates that the answer to a problem is not just searched from qaul or ulemas' opinions, but detailed answers are given to various possible problems. It seems that this istinbāt model is the most powerful type of legal effort among students, and it is undertaken by students who already have strong knowledge in understanding classical books, even studying the books of usul fiqh. It can be understood that there are several understandings grounded in fiqhiyyah rules although those understandings are taken from books. As in the example, the deliberation considers smaller mafsadat according to the rules of $i d h \bar{a}$

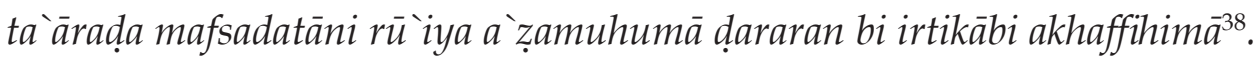

\section{TEXTUALITY AND LIMITED CONTEXTUALITY}

The Tablighi students seem like the students of other traditional Pesantren in terms of bahth al-masa'il tradition, in which they more likely rely on the answers to problems raised based on the texts they know. In some of the bahth al-masa'il results written in Temboro students' magazines, the answers are generally provided directly based on ulemas' qauls (opinions) in the books they studied in the classes of madrasah diniyyah. In general, bahth al-masa'il forum directly quotes the qaul and makes conclusions that could provide answers to the questions posed in the forum.

The above application examples exhibit students' textuality in providing answers. The depiction of this discussion confirms that Tablighi students hold strongly ulemas' qaul (opinions) as stated in the books they have learnt. This textuality does not violate the rules because students seem to realize their limitations in doing 'ijtihad' to obtain a definite law. The way of submission to ulemas' opinions from the fiqh books that they have learnt is not a kind of blind taqlid, but rather to their accuracy in viewing that those matters, from the perspective of bahth al-masa' $\bar{a}^{\prime} i$ forum, have fulfilled the expected answers.

Yahya $^{39}$ mentioned that students' submission to ulemas' qaul or opinions

38 Abdul Hamid Hakim, Mabādi' Awwaliyyah fi Ushul al-Figh wa al-Qawā̄ì al-Fiqhiyyah (Kairo: Maktab, 1927), 35.

39 Imam Yahya, "Akar Sejarah Bahtsul Masa'il: Penjelajahan Singkat," in Kritik Nalar Fiqih NU: Transformasi Paradigma Bahtsul Masa'il, 1st ed. (Jakarta: LAKPESDAM NU, 2002), 20. 
indicates two important things. First, they follow the scriptures, namely the texts of play (the rules for a game). As it is understood that the classic books in the Pesantren's fiqh tradition are the works of classical ulemas in the 13th to 19th century AD. Although many have criticized that the books were composed in a period of stagnation or taqlid in fiqh ulemas, they still have relevance to the community afterward. Second, traditionalism has the basic meaning of passing of beliefs or customs from one generation to the text. The inseparableness of classical texts in the discourse of Islamic law studied by Temboro students demonstrates that there is a transmission of knowledge from classical ulemas' generation to the community of students in today's modern life.

This condition confirms Esposito's opinion ${ }^{40}$ that makes the categorization of religious thoughts in Indonesia, namely restriction of traditionalist, modern scripturalism, and socio-historical approach. The first group is the traditionalist group that follows the strong religious traditions of its predecessors. They suffice their knowledge and understanding only based on those that already exist. The second group is a group that is still fixated on religious texts as the bases for doctrine and transformation in modern society. In the meantime, the last is a group that according to Esposito is expected to carry out a transformation of modern Muslim society that has a fundamental understanding rooted in its social and history.

Temboro students' legal istinbāt still seems to be fixated on the first model, namely restriction of the traditionalist. This is an evident from the results of decisions that are very fixated on ulemas' opinions (qaul) as found in texts. However, Temboro students' textuality in legal matters is sometimes not rigid. There are other aspects that they have taken by paying attention to benefits without leaving the texts. It indicates that there is an effort to understand the texts more broadly, by paying attention to contexts without leaving the texts. Of problems discussed in the examples of the analytical qauli method application, the model of number three above shows the existence of text contextualization efforts. The case of praise before congregational prayer is legally categorized as mubah (allowed) even sunnah (recommended), but by giving some consideration. For instance, if the praise or compliments give more negative effects than the benefits, the law is then categorized as makruh.

The contextualization in Temboro students' bahth al-masa' $i l$ forum may exist in the model of $i$ ih $\bar{a} q^{41}$, that is to equate a problem that does not have a direct qaul leading to an answer, but some instructions can be used as a foothold by similarity to legal 'illat (legal reasons). An example of a case that can receive attention, in this

40 John L Esposito, The Oxford Encyclopedia of the Modern Islamic World (New York-Oxford: Oxford University Press, 1995), 14.

${ }^{41}$ Ma'mun, "Ilhaq Dalam Bahtsul Masa'il NU; Antara Ijtihad Dan Ikhtiyat." 
case, is the issue discussed as regards "how is the law on taking retirement salaries for women who remarry using sirri?" The bahth al-masa'́il forum decides that it may not allowed ${ }^{42}$. This decision rests upon the qaul contained in the books of Nihayat alMuhtāj, Sharah Minhāj (Vol. 20, p. 134, and Vol. 28, p. 432). The qaul certainly does not speak directly about taking salaries of retired governmental officials and wives who marry in a sirri way. However, this problem is made in a way of $i l h \bar{a} q$ with people who give and who beg admitting that they are faqir, salih, or have a relation with nasab. If it is only to confess, but the situation is different, to take it is not allowed.

This form of contextualization is quite sufficient by searching for the extent of similar problems (qiyas) in the context of qauliyyah method. In several contexts of problems, Temboro students' bahth al-masa'il forum has applied it. The contextualization of fiqh understanding as such certainly requires a set of knowledge and a shared agreement of each participant in bahth al-masá ${ }^{\prime} i l^{43}$. It seems that the Tembboro Tablighi students can do it although it perhaps deals with some debates for the sake of acquiring the right understanding.

\section{CONCLUSION}

The istinbāt method in Tablighi students' bahth al-masä'il forum at Temboro is not different from the bahth al-masa' $i l$ forum at other traditional pesantren, namely providing legal answers according to the classical ulemas' qaul contained in the kitab kuning. This istinbāt effort is still limited to the model of qauliyah in a way that makes use of qaul or opinions as stated in the texts. Some problems are sufficient to be answered using one qaul, but there are also those answered using two or more qaul from different books.

In general, students are still fixated literally although there are efforts made to understand a problem with more comprehensive answers. In the meantime, the analysis efforts by analyzing texts to find legal norms have not been applied much in the bahth al-masā'il forum. The efforts of fiqh contextualization in Temboro students' bahth al-masä'il are still limited to $i l h \bar{a} q$, that is to equate a case that has no direct answer from an ulema's qaul by taking similarities to the existing 'illat. However, this way has not been applied much so that the istinbāt is still regarded as being fixated on texts.

\footnotetext{
42 This issue is addressed in Madinah magazine, volume 14, 2018. See "Masail: Hukum Mengambil Gaji Pensiunan Bagi Janda PNS Yang Sudah Menikah Lagi Dengan Nikah Sirri," 33.

43 Hosen, "Nahdlatul Ulama and Collective Ijtihad."
} 


\section{REFERENCES}

\section{Journal}

Abdillah, Kudrat. "Kontribusi Bahtsul Masail Pesantren Di Madura Dalam Menghadapi Perkembangan Hukum Islam Kontemporer." Perada: Jurnal Studi Islam Kawasan Melayu 2, no. 1 (2019): 67-80.

Ali, Jan A. "Islamic Revivalism: The Case of the Tablighi Jamaat: Journal of Muslim Minority Affairs: Vol 23, No 1." Journal of Muslim Minority Affairs 23, no. 1 (2003). https:// doi.org/10.1080/13602000305935.

Aminuddin, Luthfi Hadi. “Istinbat Jama'i Dan Penerapannya Dalam Bahtsul Masail." Al-Manahij: Jurnal Kajian Hukum Islam IX, no. 2 (Desember 2015): 237-53.

Arifin, Zainal. "The Authority of Spiritual Leadership at Pesantren Temboro Based on Jamaah Tabligh Ideology." Jurnal Pendidikan Islam 6, no. 2 (December 27, 2017): 265-92. https:/ / doi.org/10.14421/jpi.2017.62.265-292.

Hasyimi, Muhammad Luthvi Al. “Dampak Faham Keagamaan Jama'ah Tablig Terhadap Perubahan Sistem Pendidikan Di Pondok Pesantren Al Fatah Desa Temboro Kecamatan Karas Kabupaten Magetan. Muhammad Luthvi Al Hasyimi." Jurnal Intelektual: Jurnal Pendidikan Dan Studi Keislaman 7, no. 1 (May 20, 2017): 99-108. https:/ / doi.org/10.33367/intelektual.v7i1.365.

Hidayatulloh, M. Syarif. “Pembelajaran Kontekstual Dalam Kegiatan Bahtsul Masail Santri Di Pondok Pesantren Al-Muhibbin Bahrul Ulum Tambak Beras Jombang." Nazhruna: Jurnal Pendidikan Islam 1, no. 2 (August 2018): 177-200. Hosen, Nadirsyah. "Nahdlatul Ulama and Collective Ijtihad." New Zealand Journal of Asian Studies 6, no. 1 (June 2004): 5-26.

Karimuddin, Muhammad Muhdi. "Kedudukan Madzhab, Taklid Dan Ijtihad Dalam Islam.” Al-Qadha 6, no. 1 (January 2019): 55-65.

Khasanah, Nur, Achmad Irwan Hamzani, and Havis Aravik. “Taqlid dan Talfiq Dalam Konsepsi Hukum Islam." Mizan: Journal of Islamic Law 3, no. 2 (December 13, 2019): 155-68. https:/ / doi.org/10.32507/ mizan.v3i2.489.

Khoiri, M. Alim. "Ijtihad Kontemporer: Konsepsi, Urgensi dan Kritik terhadap Isu Ttertutupmnya Pintu Ijtihad." SAMAWAT 2, no. 2 (December 1, 2018). http://jurnal.staiba.ac.id/index.php/samawat/article/view/80.

Khummaini, Yusuf, and Sukron Mamun. “Jodoh dan Perjodohan Santri Jamaah Tabligh di Pesantren Temboro. "Ulul Albab: Jurnal Studi dan Penelitian Hukum Islam 3, no. 1 (January 12, 2020): 23-48. https:/ / doi.org/10.30659/ jua.v3i1.7586. 
Sukron Ma'mun \& Ilyya Muhsin, Istinbāt Method of Tablighi Students in Pesantren Temboro ...

Ma'mun, Sukron. "Ilhạq Dalam Bahtsul Masa'il NU; Antara Ijtihad Dan Ikhtiyat." Al Qalam 28, no. 1 (April 29, 2011): 63-86. https:/ / doi.org/10.32678/alqalam. v28i1.512.

Mamun, Sukron. "Tablighi Jamaat, An Islamic Revivalist Movement and Radicalism Issues." Islam Realitas: Journal of Islamic $\mathcal{E}$ Social Studies 5, no. 2 (December 18, 2019): 145-59. https://doi.org/10.30983/islam_realitas. v5i2.1098.

Ma'mun, Sukron, Muhamad Chairul Huda, Ilyya Muhsin, Afriani Maifizar, and Muhammad Zikri. “Jamaat Tablighi and Negotiation of Identity in the Global World." Opcion 36, no. 26 (2020): 821-32.

Metcalf, Barbara D. "Living Hadith in the Tablighi Jama at." The Journal of Asian Studies 52, no. 3 (1993): 584-608. https:/ / doi.org/10.2307/2058855.

Munir, Ahmad. “Akar Teologis Etos Kerja Jamaah Tabligh Studi Kasus Komunitas Jamaah Tabligh Desa Temboro Kecamatan Karas Magetan." Kodifikasia 11, no. 1 (August 17, 2017): 50-71-71. https://doi.org/10.21154/kodifikasia. v11i1.1137.

Nasih, Ahmad Munjin. “Bahtsul Masail Dan Problematikanya Di Kalangan Masyarakat Muslim Tradisional." Al-Qonun 12, no. 1 (June 2009): 106-29.

Nofialdi. "Peran Nahdatul Ulama (NU) Dalam Pembangunan Hukum Islam Di Indonesia." AL-QISTHU 17, no. 1 (2019): 11-18.

Noor, Farish A. “The Spread of the Tablighi Jama' at across Western, Central and Eastern Java and the Role of Indian Muslim Diaspora." Working Paper, 2009. https://dr.ntu.edu.sg/handle/10220/6100.

Romlah, Futiati. “Peran Jama'ah Tabligh Dalam Pembinaan Pendidikan Agama Islam Pada Masyarakat Desa Temboro Kecamatan Karas Kabupaten Magetan." Cendikia 9, no. 1 (2011).

Safe'i, Abdulah. “Redefinisi Ijtihad dan Taqlid: Upaya Reaktualisasi dan Revitalisasi Perspektif Sosio-Historis." ADLIYA: Jurnal Hukum dan Kemanusiaan 11, no. 1 (2017): 25-40. https:/ / doi.org/10.15575/adliya.v11i1.4850.

Yusuf, Moh. "Gerakan Khuruj Fi Sabilillah Sebagai Upaya Edukasi Membentuk Karakter Masyarakat: Studi Kasus Dakwah Jama'ah Tabligh Temboro Magetan Melalui Pendekatan Framing." Kontemplasi: Jurnal Ilmu-Ilmu Ushuluddin 5, no. 1 (June 9, 2017): 165-194-194. https:/ / doi.org/10.21274/ kontem. 2017.5.1.165-194.

\section{Book}

Afkar, Tim Redaksi Tanwirul. Figh Rakyat; Pertautan Fiqh dengan Kekuasaan. Yogyakarta: LKiS, 2000. 
Al-Fatah, PP. “Al-Kutub al-Muqorroroh, Program Pondok Pesantren Al-Fatah Temboro Karas Magetan Jawa Timur." PP Al-Fatah Temboro, tanpa tahun.

Farahidi, Khalil bin Ahmad. Kitāb Al-'Ain. Beirut: Dar al-Kutub al-Ilmiyah, 2003. Hakim, Abdul Hamid. Mabādi' Awwaliyyah fi Ushul al-Figh wa al-Qawā id alFiqhiyyah. Kairo: Maktab, 1927.

Hilal, Haitsam. Mu'jam Mușțalah al-Ușūl. Beirut: Dar al-Jael, 2003.

John L Esposito. The Oxford Encyclopedia of the Modern Islamic World. New YorkOxford: Oxford University Press, 1995.

Ka'bah, Rifyal. "Formulasi Hukum Di Kalangan NU." In Kritik Nalar Fiqih NU: Transformasi Paradigma Bahtsul Masa'il. Jakarta: LAKPESDAM NU, 2002.

Khalil, Rasyad Hasan. Tārikh al-Tashri'. Jakarta: Amzah, 2009.

Khon, Abdul Majid. Ikhtiṣār Tārīkh al-Tashri'. 2nd ed. Jakarta: Amzah, 2015.

Masyhuri, A Aziz. Masalah Keagamaan Hasil Muktamar Dan Munas Ulama NU Kesatu 1926 s.d Ke-29 1994. Surabaya: PP RMI dan Dinamika Press, 1997.

Muhammad, Husein. "Tradisi Istinbath Hukum NU: Sebuah Kritik.” In Kritik Nalar Fiqh NU: Transformasi Paradigma Bahtsul Masa'il. Jakarta: LAKPESDAM NU, 2002.

Munawwir, A. Warson. “Kamus Al-Munawir." In Kamus Al-Munawir. Surabaya: Pustaka Progressif, 2007.

Noor, Farish A. Islam on the Move: The Tablighi Jama'at in Southeast Asia. Amsterdam: Amsterdam University Press, 2012.

Said, Imam Ghazali. Dokumentasi dan Dinamika Pemikiran Ulama Bermadzhab' dalam Solusi Problematika Aktual Hukum Islam: Keputusan Muktamar, Munas, dan Konbes Nahdlatul Ulama 1926-1999 M. Surabaya: LTNU Jawa Timur, 2004.

Sanu, Qutb Musthafa. Mu'jam Muștalaḥāt Ușūl al-Fiqh. 1st ed. Damaskus: Dar al-Fikr, 2000.

Yahya, Imam. "Akar Sejarah Bahtsul Masa'il: Penjelajahan Singkat." In Kritik Nalar Fiqih NU: Transformasi Paradigma Bahtsul Masa'il, 1st ed. Jakarta: LAKPESDAM NU, 2002.

\section{Magazine}

Al Fatah, Darul Ifta'. "Masa'il Fiqhiyyah: Keputusan Bahtsul Masa'il Spesial Romadhon." Majalah Al-Maktabah, 2018.

Bangka, Fadhil, and Amin. "Kawah Candradimuka Itu Bernama Al-Fatah (Bagian 1 Selayang Pandang Pesantren Al-Fatah)." Majalah Tranqil, 2018.

Ifta', Darul. "Bahtsul Masail." Majalah Humairo Santri Putri Al Fatah Temboro, 2018. "Masail: Hukum Mengambil Gaji Pensiunan Bagi Janda PNS Yang Sudah Menikah Lagi Dengan Nikah Sirri." Majalah Al-Madinah, 2018. 
Sukron Ma'mun \& Ilyya Muhsin, Istinbāt Method of Tablighi Students in Pesantren Temboro ...

Masail, Tim Bahtsul. "Masail: Kreteria Alat Musik Yang Diharamkan Dalam Shalawatan." Majalah Al-Madinah, 2018.

\section{Website}

Cah Temboro. “Santri Pondok Pesantren Al Fatah Temboro Mencapai 19.604 Santri, 646 Santri Dari Luar Negri." Accessed May 4, 2020. http:/ / cahtemboro. blogspot.com/2016/12/ santri-pesantren-al-fatah-temboro.html.

\section{Interview}

Imron, interview, August 2019. 